\title{
Factors Affecting the Acceptance of Mobile Banking by Customers Case Study: The Branches of Tejarat Bank in Rasht City
}

Fatemeh Aghajani Golsefid

M.A. of Business Management, Rasht Branch, Islamic Azad University, Rasht, Iran

\section{Fereidoun Davoudi Kiakalayeh}

Corresponding Author; M.A. of Business Management, Firoozkooh Branch, Islamic Azad University, Firoozkooh, Iran

\author{
Doi:10.5901/mjss.2016.v7n2s1p518
}

\begin{abstract}
This study is conducted to identify factors affecting the acceptance of mobile banking by Tejarat bank customers. The main models used in this study are the adoption of technology model and innovation and publishing model. This research method is descriptive - survey and in terms of purpose is practical. The population of this study is customers of Tejarat Bank city of Rasht, and a sample of 393 of these clients has been investigated. To analyze the data and test hypotheses PLS structural equation modeling methods were used.The results indicate that that perceived usefulness and ease of use are two important factors were identified in the acceptance of mobile banking. While the perceived risk and costs have no impact on the acceptance of mobile banking.
\end{abstract}

Keywords: Acceptance mobile bank, perceived usefulness, perceived risk, ease of use and Tejarat Bank.

\section{Introduction}

The service industry in the world is changing. New technologies have changed methodology services to customers in many service organizations. Increasing development of information technology is an effecting and accelerating factors of financial sector and its servicesAnd electronic financial services either by Internet or via mobile phone or other means of remote transmission or through smart cards has rapid expansion and has changed nature of the financial services around the world strongly (Ajzen,1991).Advances in technology and wireless devices in recent years, has created new opportunities to offer new banking services, as mobile banking. With mobile banking, customers can at any place and time, quickly and easily benefit from banking services (Karkhaneh, 2012). Since the diffusion of mobile devices is higher than other technologies, mobile banking, if accepted by the customer can be effective in reducing costs for banks and consumers. Technology and wireless devices have improved in recent years and statistics of users of wireless devices in the world is increasing. These developments have created new opportunities to provide new banking services as mobile banking (Karkhaneh, 2012).Mobile banking is from branches of e-banking that it means doing banking through a mobile device like a mobile phone. With the introduction of mobile banking, banks can retain their current customers in the existing systems and have the opportunity that mobile phone users will be transform to their customers (Gu et al, 2009). Mobile banking is of one of the approaches to providing financial services through information and communication technologies that enables a wide selection of mobile phone services even in low-income countries (Anderson, 2010). This approach is in fact developed Internet banking and home banking, in this way people are using their handheld computers with mobile connection to the main network communication of bank (Internet or other private networks of banks) for financial services.Using a mobile phone can do many banking operations as residuals in the accounts, stop payment Czech, transfer money from one account to another and etc.(Hasanzadeh, 2002). Marketing scholars and practitioners can interpret these results as helping to justify expenditures on brand and customer related marketing activities that create such long-term brand relationships with their consumers. (Taleghani et al., 2011) Investment is a key variable which has an interactive relationship with many economic variables like industry growth. Governments provide conditions for attraction and direction of investment via appropriate incentives. Governments approve regulations for supporting investors. Managers must have special features and competencies and long experiences and socio-communicational skills. We must start from targets in order to have effective management and managers must rely firstly on their resources and especially workforce (Rahnama et al., 2011). In any organization, whether service or production, customer is the 
main factor for survival and success of the company. If an organization fails to attract customers' satisfaction and loyalty, it will not be sure about its long-term activity (Vazifehdoost, Rahnama\&Mousaviyan, 2014). The factor that has attracted banks' attention to mobile banking strongly is unique features of mobile services that reduce costs of banking services (Vafaei, 2010). Changes in the type of transaction by bank customers to do business from the physical presence of customers in branches and to the use of postal services to transport and deposit money bank and other banking operations, Transaction over the phone and contact center with customers, using phone keys to interact with bank and audio and video answer, banking via PC, using a modem and special software, and finally use of the Internet reflects the historical developments that led to the improvement and increase the variety of banking services to customers (Shafaei, 2013). Investigate the factors influencing the use of electronic banking and Mobile banking services in Iran, requires a comprehensive and thorough study and research. Today banking industry is changing quickly. With the development of the international economy and competitive markets, banks have also been affectedand in this environment, technology is the main force that has breaking legal, geographical and industrial barriers and has created new products and services. According to available statistics, the penetration rate of mobile phone usage is higher than any other technology. This issue is made the mobile commerce in the form of global revolutionary (Monfared, 2013).Since mobile banking is new, compared to other electronic banking services, there is this possibility that cannot find its place in modern banking.Therefore, identifying factors influencing customer decisions to use Mobile banking is binding.

\section{A Review of the Literature and Theoretical Framework}

Today world is moving toward being electronic and Mobile banking is one of the most popular trends in e-commerce which not only because of the attractiveness of the Internet, but because of e-business, including virtual processes such as the chain of supply and demand financial reporting and the reports of the customers (Sathye, 1999). Today technologies such as ATM, internet banking, phone banking and mobile banking have great importance and necessity because in recent years as a method of maintaining customer loyalty and increasing market share gained popularity.Banks use technology to meet the challenges that imposed by competition and online banks and also as a way to reduce the cost of providing services that when done exclusively by a bank employee. Development of IT and establishment of banking services based on these new technologies, leads to the emergence of new services. The use of these services depends on infrastructure and the laws of countries. In most countries with strong telecom infrastructure, mobile banking is the best, fastest and most convenient financial services. These banking services because of lack of the need to attend in the branch and even without a PC or special environment, is considered as one of the desirable service for customer (Rashidi, 2008).

Taking advantage of each of the ports of electronic banking and its impact on individuals chooses with different tastes and interests, banks compete together by represent different services, in terms of different ports, type of service in a competitive market of electronic banking.Customer-oriented in competitive market is the most important factor (Proceedings of Faba, 2008).Amounts of exchanges over the Internet are growing every day and companies that do not use this technology, within a short time will disappear from the market.In this regard, many banks globally to provide electronic services because they know that their survival principle is speed of service and Informed of customer demand (Liao,Z.and Tow Chung,M.,2002).

Today, e-banking before an advantage, is a necessity.First because virtual and electronic banks through the Internet are able to provide faster, more complete, more accurate, more desired services to customers all over the world. Secondly, the slowness of the traditional system causes that banks lose a golden opportunity to attract customers (SeyedJavadian, 2009). Due to the large investment of banks for the development of information systems, and use of information technology to provide better services, understanding the factors that led to the acceptance these technologies, is the most important factors in the field of information technology research (Venkatesh,V.and Davis,F.D.2000).Always identify and understand the advantages of new technologies in organizations and its impact on their performance, has been a very important issue for financial services and banking industry (Agarwal et al., 2009).

In this regard, the use of mobile banking services in these institutions can create value for them.Users through mobile banking have access to banking services such as manage account, transfer money, pay bills, etc.It helps banks improve their service quality and reduce service costs (Zhou,et al,.2010). Success in this task depends on the acceptance these technologies by customers and users of these institutions (Behboudi\& et al, 2013).

With regard to the items listed in the field of Mobile banking services, a conceptual model for this study was obtained. This model has been designed according to study different articles in this field and modeled from journals in the field of electronic banking, in particular theoretical model of technology adoption, innovation diffusion theory to identify factors affecting the acceptance mobile banking. Theory of technology acceptance which is provided by Davis, is one of 
the theories used in studies of Information system adopting. This theory states that perceived usefulness and ease of use is effective on the mindset of people associated with the use of information systems. Technology Acceptance Model (TAM) is one of the acceptable and widespread models in the field of information technology. It describes the nature of the relationship Belief- attitude intention-behavior and its relationship with the Acceptance use of technology information (Behboudi\& et al, 2013). Many studies (TAM) have been used to analyze consumer behavior, especially in the use of different types of information systems (Agarwaland Prasad, 1999).

Theory of diffusion of innovation is another famous model in the use of new technologies by users. In this theory, the publication is defined as a process in which an innovation through certain channels over time communicates with the members of a community. Accordingly, users are examined an innovation based on some of the features such as relative advantage, compatibility, complexity and ability test.Two features of the cost and perceived risk in 1997 were added to the theory (Lockett, 2000).

\section{Previous Research}

Many articles in accepting all types' mobile technologies, Internet and e-commerce provided. Heuristic methods have used more to determine the causes of the rejection electronic banking by some customers, in 1998 and 2005. But in 2005 and after that in the most of the researches have been used the statistical verification methods for determining the effective factors in acceptance of electronic banking. Also process of research shows gradually acceptance of Internet bank and after that mobile banking has been the spotlight of researchers (Hashemian, 2011).

Yu in 2012 investigate factors affecting on the acceptance of mobile banking in the country's Taiwan. He has used unified theory of acceptance and using technology for this purpose.Factors that the impact of them checked in model of this study include:expected Efficiency, the expected effort, social influence, facilitating conditions, perceived reputation, perceived financial costs and perceived self- ability.From the influence of perceived self- ability and expected effort to decide on the use of mobile banking was rejected.

Another study by Nurdin Abdul Qadir with the topic "Providing the Model for acceptance of mobile banking" has done in 2010 in Malaysia. In this study, by using models of TAM IDT, TPB, DTPB shows that social factors and comparative advantage have the greatest influence in the acceptance of mobile banking.

Riquelme and Rios (2010) examined the effect of gender in the acceptance of mobile banking. They considered risk factors, ease of use, usefulness, comparative advantages and social norms in their model and showed the risks, benefits and social norms have the most impact on acceptance and also the impact of the ease of use in women is more while comparative advantage in men is more effective. Social norm is more effective in women than in men.

Chong Ming studied "Mobile Security Bank in South Africa" in 2010. The author in this study notes that banking through mobile is a proper approach for doing banking Affairs remotely,but the security that have been used in this network is not enough.GSM is used as the loneliest means of data transmission in the network.Conducted Studies by researcher indicate that banks with the use of SMS and GPRS can increase mobile security systems.

Crabbe and et al (2009) by studying the social and cultural factors affecting the acceptance of mobile banking in Ghana showed that in addition to observed Credibility, facilitating conditions and demographic factors also have a clear impact on the acceptance of mobile banking.

Research in 1392 by KonjkavMonfared and et al as "investigate factors affecting acceptance of Mobile Bank by customers of Saderat Bank in Yazd," was conducted.Results of this study showed that all identified factors (compatibility, Visibility, anxiety, education, information quality, service quality and trust) have direct or indirect effect on the Members' actual use of mobile banking.

MojdehHashemian and et al have done a study as "Review and identify key factors in the acceptance of mobile banking by customers" in 1390. In this research have been studied the customers of Saman Bank. The results show that quality of service, trust, expected performance, expected effort, easing conditions, information about services, selfefficacy and personal Innovation have significant impact on the acceptance of mobile banking.But a sense of risk towards personal innovation andand self-efficacy and awareness has less impact on acceptance.

Mohammad Taghavifardln a study as "Factors affecting of using mobile banking services by customers and ranking them (Case study: Tejarat Bank branch in Tehran) in 1389has taken To identify the factors influencing on the use of mobile banking services with the use of a model that factors affecting on the use of mobile services divided into three segments, mobile banking technology features, psychological characteristics and demographic characteristics. Considering the results of this research, between characteristics of mobile banking technology, was priority, variables of compatibility, cost of using, capability of test and usefulness are more effective.While the complexity and perceived risk, in this case, does not have much impact.Among the psychological characteristics, in order of priority, risk and thinking 
around change are effective factors. While the leadership of opinion in this case, does not have much impact.

SamanehSarvarnejadexamines Research entitled "Determination New strategy of banking in the rate acceptance of Members 'mobile banking service in private banks" in 1389.Results of this study indicate that the Members acceptance of mobile banking depend on the percentage of people risk appetiteln other words, it can be assumed that people who are high risk and are more willing than others to show the innovation are most welcome to this service (Sarvarnejad, 2010).

So this study investigates the factors influencing on the acceptance of mobile banking by the customer.And after studies and researches documents and with the use of literature offers a model for research that in this regard original question of research is as follows:

What are the Key factors influencing on acceptance of mobile banking by the customers of Tejarat bank branches of the city of Rasht?

\section{Conceptual Model}

For scientific and systematic research, scientific and theoretical framework is needed that so-called conceptual model. That conceptual model in this study is as follows.

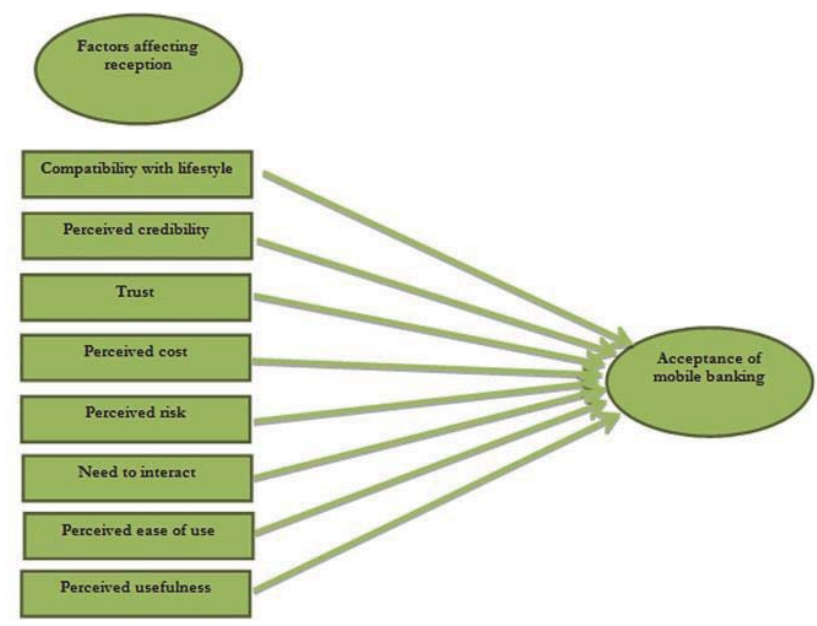

Figure 1: Conceptual Model, (Hanafizadeh\& et al, 2014)

\section{Conceptual Definition of Variables}

- Compatibility: The extent to which an innovation is compatible with existing values, past experiences and current needs of potential adopters (Taylor\&Todd, 1995). Consistency is one of the oldest and most important factors to determine customer attitudes towards e-banking services and the use of it (Wu and Wang, 2005).Also compatibility defined to the attunement of banking services with the lifestyle and needs of customers (Hourahine and Howard, 2004).

- Perceived credibility: Credibilitydefined as the reliability of the system and the ability to transfer and transactions (ErdemandSwait, 2004). In other words, the lack of reliability of service providers leads to reducing the likelihood of its acceptance by customers (Luarn and Lin, 2005).

- Trust: Trust has been defined as a desire to ensure to a business partner that has reliability (Das and teng, 2001).Also trust has defined as confidentiality of information and lack of access of others to personal information (http:/matt.rozblog.com).

- Perceived cost: Perceived costis the applications of goods and services according to the financial costs. In fact, any spending resources are in order to obtain the benefits in the future. One of the barriers to adoption of new technologies is usually high cost of using them. 
- perceived risk: Action to which the risk exists, called risk. On the greater the risk is the fear caused by lack of access of plan or project, to some pre-determined objectives.

- the need to interact: The order of need to interact in this study is customer-person bargaining with employees.Need to interact to create and maintain a personal connection while the user of use personal service, is appropriate (Dabholkar, 1992; Dabholkar, 1996).

- Perceived ease of use: Refers to the degree to which a person believes that learning how to use a particular technology requires little effort in terms of mental (SeyedJavadian, 2009).

In another definition, ease of use is remembered to the person's belief that a system can be used without much effort (Davis, 1989).

- Perceived usefulness: Usefulness refers to the degree of technological innovation has benefits such as economic, increase comfort and satisfaction with it (Rogers, 1983).

Also extent to which a person believes that using a particular system adds his/her performance levels. Also the degree which a technology causes more advantage with existing facilities on equal terms (Vankatesh et al, 2003).

\section{Hypotheses}

Hypothesis 1: Compatibility with lifestyle has a direct impact on the adoption of mobile banking.

Hypothesis 2: Credibilityhas a direct impact on the adoption of mobile banking.

Hypothesis 3: Trusthas a direct impact on the adoption of mobile banking.

Hypothesis 4: Perceived cost has an adverse effect on the adoption of mobile banking.

Hypothesis 5: Perceived risk has an adverse effect on the adoption of mobile banking.

Hypothesis 6: Need to interact have an adverse effect on the adoption of mobile banking.

Hypothesis 7: Ease of use has a direct impact on the adoption of mobile banking.

Hypothesis 8: Perceived usefulness has a direct impact on the adoption of mobile banking.

\section{Research Methodology}

This research purpose is an applied one and is a descriptive and survey study; becausedescriptive method has used for the extraction of research literature and to collect the required data from the survey. This research for six months in the first half of 2014 in the city of Rasht was conducted. The population of this study is patrons and customers of Tejarat Bank city of Rasht.In this study, available and non-probability sampling at the location of branches have been used. Required sample size in this study, was extracted from the table determining sample size of a given population of the "Morgan" and a sample of 393 patients were studied.

In this study, a questionnaire was used to collect information which contains indicators for measuring the factors affecting acceptance of mobile banking by customers. In order to quantify the variables of the whole five-Likert (strongly agree, agree, somewhat agree, disagree, strongly disagree) was used. In this study, Cronbach's alpha coefficient was calculated to assess reliability. Also to test the community normal distribution, the Kolmogorov-Smirnov test was used. Given that the variables had not normal distribution, therefore, to analyze data, structural equation modeling was used to PLS method.

\section{The Results}

In this study, a path analysis model is used to examine the relationship between variables based on the conceptual model. Path analysis is a multivariate analysis technique that allows researchers to examine a set of regression equations simultaneously.Composite credibility of each construct that is also known as composite reliability (Composite Reliability)and it is a more modern criteria for determine the reliability rather than the Cronbach's alpha and it has obtained from Dillon - Goldstein coefficient, that all values greater than 7.0 are acceptable.To evaluate the validity of model, the criteria introduced by "Fornell and Larkr" was used that based of it, all structures have an appropriate valid.After ensuring that the appropriateness of measurement models, the structural model that includes Path Analysis (Beta), significance of path coefficients and the amount of explained variance (R2) has been review and test. The results of structural equation modeling and approve or reject the hypothesis can be seen in Table 1. 
Table 1. Hypothesis test results

\begin{tabular}{|lccc|}
\hline Hypothesis & T-statistics Path coefficient & Result \\
\hline Compatibility with lifestyle has a direct impact on the adoption of mobile banking. & 15.53 & .20 & Confirm \\
\hline Credibility has a direct impact on the adoption of mobile banking. & 3.95 & .05 & Confirm \\
\hline Trust has a direct impact on the adoption of mobile banking. & 4.53 & .06 & Confirm \\
\hline Perceived cost has an adverse effect on the adoption of mobile banking. & 4.59 & .03 & Rejection \\
\hline Perceived risk has an adverse effect on the adoption of mobile banking. & 5.39 & .08 & Rejection \\
\hline Need to interact have an adverse effect on the adoption of mobile & 1.97 & -.02 & Confirm \\
\hline Ease of use has a direct impact on the adoption of mobile banking. & 20.61 & .22 & Confirm \\
\hline Perceived usefulness has a direct impact on the adoption of mobile banking. & 35.49 & .45 & Confirm \\
\hline
\end{tabular}

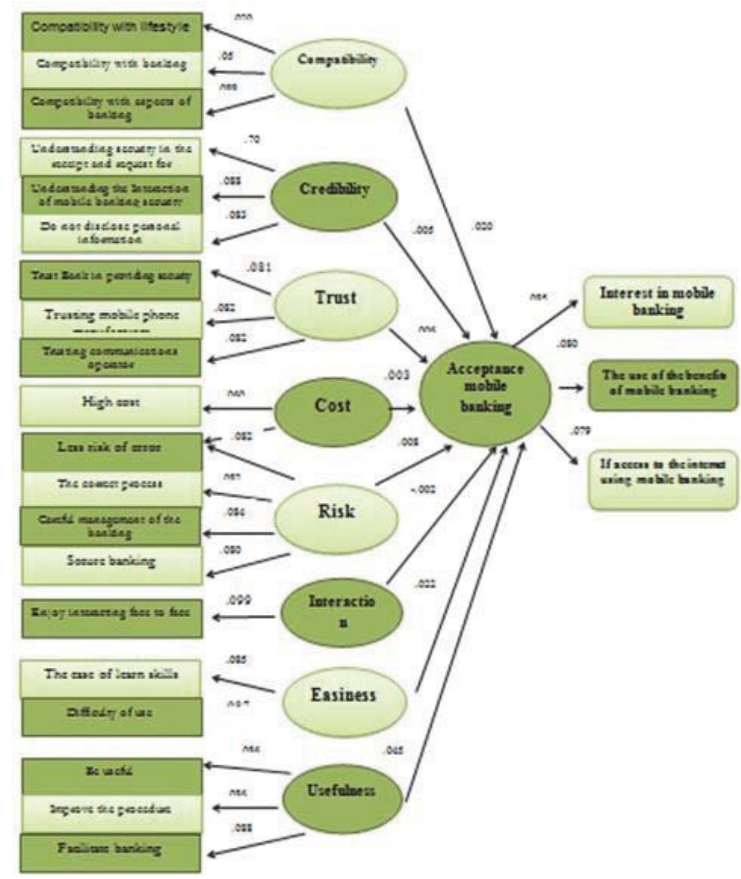

Figure 2: Path Analysis

\section{Summary and Conclusion}

In the present era due to the increasing development of information and communication technology, there have been many methods for more comfortable life.Mobile banking is known as an innovation in modern banking. Experts of this Technology are trying to use this technology and use this technology in order to facilitate their daily activities so that they can in the shortest time and with the lowest cost and independent of time and place communicate with their customers.Meanwhile, widespread use of mobile in our country has caused creating an opportunity for banks to turn to the banking through this method.Also customers of banks and the banks profited from the diverse benefit of this technology.In this study, the framework of integration of technology adoption model and diffusion of innovation is examined.Results of this study show that perceived usefulness and ease of use have been identified two key factors in the acceptance of mobile banking.In other words, customers must become aware of the advantage of acceptance mobile banking such as Savings time and place and speed of conducting transactions through electronic systems.So that customers understand that conducting transactions through electronic systems has advantage instead of standing in long queues at branches.Also banks should be able to run most of the available banking services at branches through mobile 
banking system for their customers.Also managers of banks should be able to use incentives policies and various advantages of customers will notice the difference between traditional and modern banking.Because otherwise we cannot without enumerate this difference and the benefits of this technology guidance and encouragement them to use mobile banking.Results of present study matched with results obtained of research Kim and et al (2010) and Qing Lewis and et al (2010).

Considering to the results obtained of this study are influential ease of use of acceptance mobile banking.In this regard, we can say that the banks are using equipment that is more users friendly and customers communicate with them easier.Providing Simple and easy guidelines will affect the acceptance of mobile banking services.Because whatever customers in the use of mobile banking services feel ease and convenience and using of it is not difficult for them, they will have more willing to use this service.Therefore, banks should try to simplify web design and simplification of performing procedures of banking transactions. The result obtained of the present study has consistent coordination with the results of research Rykulmeh and Rios (2010) and Hindayn (2006). The results of checking other assumed variables in the research model showed that other variables except the perceived risk and cost affect acceptance mobile banking.Considering that it is difficult to focus on all effective factors, therefore, banks should focus most of your investment on the factors that acceptance of mobile banking from customers have decisive role than the other factors.

\section{References}

A center of culture and banking education (Faba) "Journal of Electronic Banking", 2008.

Abdulkadir, nurudeen. (2010)."A Proposed Model for M-Banking".

Agarwal, R. \& Prasad, J. (1999). "Are individual differences germane to the acceptance of new information technologies?" Decision Sciences, 30 (2), pp. 361-391.

Ajzen, I. (1991). The Theory of Planned Behavior. Organizational Behavior and Human Decision Processes, 50(2), 179-211.

Anderson, J.(2010)."M-banking in developing markets: competitive and regulatory implications",info,12(1),pp.18

Behboudi, M., 2013, Acceptance of mobile banking by Iranian customers, "Journal of Marketing Management, Issue 18.

Crabbe ,M.,Standing , C.,Standing ,S .,\&Karjaluoto,H .(2009)."An adoption model for mobile banking in Ghana .International journal of Mobile Communication ,7(5), 515- 543 .

Dabholkar, P. (1996). "Consumer evaluations of new technology-based self-service options: an investigation of alternative models of service quality", International Journal of Research in Marketing, 13(3), pp.29-51.

Das, T. D. \&Teng, B. Sh. (2001). "Trust, control, and risk in strategic alliance: an integrated framework", Organization Studies, 12 (4), pp. 251-283.

Davis, F. D. (1989). Perceived Usefulness, Perceived Ease of Use, and User Acceptance of Information Technology. MIS Quarterly, 13 (3), 319-339

Erdem, T. \&Swait, J. (2004). "Brand credibility, brand consideration, and choice", Journal of Consumer Research, 31 (1), pp. 191-198.

Handin Amin, Ricardo Baba, MohdZulkifli Muhammad. (2006)."An analysis of mobile banking acceptance by Malaysian customers", International Journal of Information Management. No, 56.

Hasanzade, A., 2004, Electronic Financial services new approach to the development of the financial sector ", Monetary and Banking Research Institute, Central Bank of the Islamic Republic of Iran.

Hashemian, M., Eisaei, M.T., Mikaeeli, f., \&Tabatabaei, M., 2012, the factors affecting of acceptance of electronic devices by customers (survey about Saman Bank), Information Technology Management, Volume 4, Issue 11, pp.155-174.

Hourahine, B. \& Howard, M. (2004). "Money on the move: opportunities for financial service providers in the Third Space", Journal of Financial Services Marketing, 9 (1), pp. 57-67.

Investigation", International Journal of Bank Marketing, 17(7),pp.324-34

Ja- ChulGu , Sang - Chul Lee, (2009)," Determinant of behavioral intention to mobile banking , Expert system with applications 36, $11605-11616 "$.

Karkhaneh, S., 2012, "providing a suggested model for acceptance of mobile banking customers' perspective and comparing it with the global models," Journal of Marketing Management, 16.

Koenig-Lewis, N., Palmer, A. \& Moll, A. (2010). "Predicting young consumers' take up of mobile banking services", International Journal of Bank Marketing, 28(5), PP.410-432.

Liao, Z and Tow Chung, M., (2002)", Internet Based E-Banking and Customer Attitudes:"An Empirical Study, Information and management,39, 283-295.

Lockett A. and Littler D. (1997) "The adoption of Direct Banking Service", Journal of Marketing Management, 13, 791-811.

Luarn, P. \& Lin, H.-H. (2005). "Toward an understanding of the behavioral intention to use mobile banking", Computers in Human Behavior. 21 (6), pp. 873-91.

Ming, chong, KI \& Kelvin, Chikomo, (2010) "Security of Mobile Banking. "Resistance", International Journal of Bank marketing. 28 (5), pp. 372-388.

Monfared, A.R., \&MIrhoseini, M., 2013, Investigate Effective Factors on acceptance of mobile Banking by customers of Saderat bank branches, "Journal of Marketing Management, 18. 
Rahnama, Afshin.,Mousavian, SeyedJavad., Alaei, Abbas., SalimiMaghvan,Tavakkol., (2011). "THE SURVEY OF RELATIONSHIP Between Creativity Of Staffs And Organizational Effectiveness" Australian Journal of Business and Management Research, Vol.1 No.6, pp.97-104.

Rashidi, D., 2008, Marketing of Banking services "Kohsar Publications, Third Edition.

Riquelme, H. E. \& Rios, R. E. (2010). "The moderating effect of gender in the adoption of mobile banking", International Journal of Bank Marketing, 28 (5), pp. 328-341.

Rogers, E.M. (1995), Diffusion of Innovations, New York: free press.

Sarvarnejad, S., 2010, Determination New strategies of banking in the amount of users' acceptance of mobile banking service in private banks, Khorasgan Islamic Azad University.

Sathye, M. (1999). "Adoption of internet banking by Australian consumers: an empirical

SeyedJavadin, R., YazdaniShamsi, 2005, Investigate factors influencing of customers' Intention using of internet banking service (study Saman Bank)" knowledge management (45).

Taghavifard, M., \&Torabi, M., 2010, Factors affecting the use of mobile banking services by customers and their ranking, Journal of Mining Business Management, second year.

Taleghani, Mohammad., Samadi Largani, Mahmood., Mousavian, Seyyed Javad. (2011). "The Investigation And Analysis Impact Of Brand Dimensions On Services Quality And Customers Satisfaction In New Enterprises Of Iran", Contemporary Marketing Review, Vol. 1(6) pp. $01-13$.

Taylor, S., Todd, P.(1995) .Understanding information technology usage:A test of competing modles.Information systems research , 6(2), 144-176.

Vafaee, N., 2010, Identify and prioritize the effective factors in acceptance of mobile banking from the customer perspective) "Case Study Melli bank branches in Iran, Tehran, MA thesis of Business Administration degree, TarbiatModarres University.

Vazifehdoost, Hossein.,Rahnama, Afshin., Mousavian, SeyedJavad., (2014). "Evaluation of the Impact of Brand Purchase Involvement, Satisfaction, Experience and Brand Trust on Loyalty to Brand" Mediterranean Journal of Social Sciences, Vol 5 No 20, pp.30543063.

Venkatesh, V, and Davis, F.D.(2002)," A Theoretical Extension of the Technology Acceptance Model: F our Longitudinal Field Studies "Management Science, Vol .46,No .2.pp186-204.

Wu, J. H. \& Wang, S. C. (2005). "What drives mobile commerce? An empirical evaluation of the revised technology acceptance model", Information and Management, 42 (5), pp. 719-729...

Yu, C-S. (2012). "Factors affecting individuals to adopt mobile banking: empirical evidence from the UTAUT Model", Journal of Electronic Commerce Research, 13 (2), pp.104-121.

Zhou,T., Lu, Y.(2010)".Bin Wang ,Integrating TTF and UTAUT to explain mobile banking user adoption," Computers in human behavior, 26(15),pp.760-767. 